\title{
Synthesis of 3-functionalized 3-methylazetidines
}

\author{
Sonja Stanković, Matthias D’hooghe, ${ }^{*}$ Kourosch Abbaspour Tehrani, \\ and Norbert De Kimpe* \\ Department of Sustainable Organic Chemistry and Technology, Faculty of Bioscience Engineering, \\ Ghent University, Coupure Links 653, B-9000 Ghent, Belgium \\ matthias.dhooghe@UGent.be, norbert.dekimpe@UGent.be
}

\begin{abstract}
Butyl- and 1-(4-methylbenzyl)-3-bromo-3-methylazetidines were prepared from the corresponding $N$-(2,3-dibromo-2-methylpropylidene)alkylamines and their propensity to undergo nucleophilic substitution at the 3-position by different nucleophiles was assessed, providing a convenient access to novel 3-alkoxy-, 3-aryloxy-, 3-hydroxy-, 3-cyano-, 3-carboxy-, 3(aminomethyl)- and 3-(hydroxymethyl)azetidines.
\end{abstract}

Key words: aziridines, azetidines, aziridinium salts, imines, substitution

Within azaheterocyclic chemistry, azetidines represent a valuable class of strained nitrogencontaining compounds from both a biological ${ }^{1}$ and a synthetic point of view. ${ }^{2}$ In particular, 3substituted azetidines have attracted considerable interest because of the diverse biological activities associated to this type of compounds. For example, 3-alkoxy- and 3aryloxyazetidines have been described as G-protein coupled receptor agonists, ${ }^{3}$ inhibitors of stearoyl-coenzyme d-9 desaturase, ${ }^{4}$ and antibacterial agents. ${ }^{5}$ Moreover, 3-haloazetidines (without an additional alkyl group at the 3-position) are generally recognized as good substrates in organic chemistry for the preparation of other 3 -functionalized azetidines. ${ }^{6}$

Recently, the convenient synthesis of 3-methoxy-3-methylazetidines $\mathbf{3}$ through ring rearrangement of 2-bromomethyl-2-methylaziridines $\mathbf{2}$, obtained by $\mathrm{NaBH}_{4}$-mediated reduction of the corresponding $\alpha, \beta$-dibromo imines $\mathbf{1}$, upon treatment with $\mathrm{NaBH}_{4}$ in methanol under reflux has been described by us. ${ }^{7}$ The same azetidines 3 have also been prepared via a different route through $\mathrm{NaBH}_{4}$-mediated cyclization of $\mathrm{N}$-alkylidene-(3bromo-2-methoxy-2-methylpropyl)amines. ${ }^{8}$ In general, halogenated imines comprise useful intermediates for the preparation of azaheterocyclic compounds such as aziridines and azetidines. $^{9}$ 
Furthermore, if aziridines 2 were heated in acetonitrile under reflux, 3-bromoazetidines 4 were obtained as the thermodynamic products (Scheme 1). ${ }^{7}$ Until then, the peculiar rearrangement of 2-(halomethyl)aziridines to 3-haloazetidines had been observed in the literature in only two specific cases. ${ }^{10}$

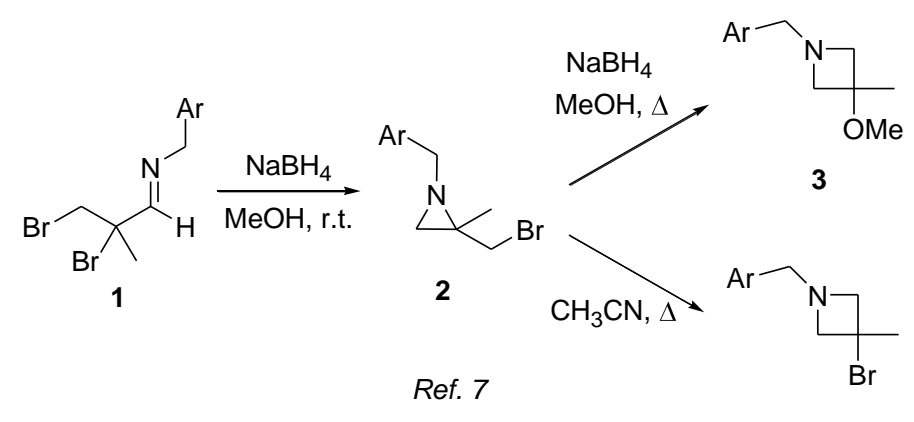

4

Scheme 1. Reactivity of 2-bromomethyl-2-methylaziridines 2.

In general, the reactivity profile of 3-bromo-3-methylazetidines as useful synthons in organic chemistry has not been studied so far. In this Letter, the synthesis of 3-bromo-3-methyl-1-(4methylbenzyl)azetidine and 3-bromo-1-t-butyl-3-methylazetidine will be covered, as well as their propensity to undergo nucleophilic substitution at the 3-position to access a window of novel 3-functionalized azetidines.

The synthesis of 3-bromo-3-methyl-1-(4-methylbenzyl)azetidine 9 was performed via thermal ring expansion of 2-bromomethyl-2-methylaziridine $\mathbf{8}$ upon heating in acetonitrile under reflux according to a literature protocol (Scheme 2). ${ }^{7}$ Aziridine 8 was prepared by reductive cyclization of $\alpha, \beta$-dibromoaldimine $7 \mathbf{a}\left(\mathrm{R}=4-\mathrm{MeC}_{6} \mathrm{H}_{4} \mathrm{CH}_{2}\right)$, obtained via bromination of 2-methylpropenal $\mathbf{5}$ and subsequent condensation with 4-methylbenzylamine in the presence of titanium(IV) chloride and triethylamine. ${ }^{7}$ In the same work, it has been shown that 3-methoxy-3-methylazetidines 3 were obtained upon treatment of imines 7 ( $\mathrm{R}=$ $\mathrm{CH}_{2} \mathrm{Ar}$ ) with sodium borohydride in methanol under reflux. Considering this smooth imine 7 ( $\mathrm{R}=\mathrm{CH}_{2} \mathrm{Ar}$ ) to azetidine 3 transformation, different reaction conditions were evaluated to obtain 3-bromoazetidine 9 directly from imine 7a. The reaction of imine 7a with 1 molar equiv of $\mathrm{LiAlH}_{4}$ in diethyl ether for 18 hours under reflux resulted only in aziridine $\mathbf{8}$, while the same reaction in tetrahydrofuran for a prolonged reaction time ( 5 days) gave a mixture of ring-opened amines derived from the hydride-induced ring opening of aziridine $8 .{ }^{11}$ The reduction of imine 7a, either with 1 molar equiv of $\mathrm{LiAlH}_{4}$ in dioxane for 15 hours under 
reflux or with 2 molar equiv of $\mathrm{NaBH}_{4}$ in isopropanol for 15-24 hours under reflux, gave complex reaction mixtures, in which no 3-bromoazetidine 9 could be detected. Therefore, the most efficient synthesis of azetidine 9 was shown to occur via thermal rearrangement of aziridine 8.

Contrary to the reactivity of $N$-(arylmethyl)imine 7a, treatment of $N$-t-butylimine $7 \mathbf{b}$ with 2.5 molar equiv of $\mathrm{NaBH}_{4}$ in methanol for 4 hours at room temperature selectively provided amine $\mathbf{1 0}$ instead of 2-bromomethyl-1-t-butyl-2-methylaziridine (Scheme 2). These observations are in accordance with the $\mathrm{NaBH}_{4}$-mediated reduction of chlorinated imines towards the synthesis of different 1-alkyl-2-chloromethyl-2-methylaziridines, except in the case of the 1-t-butyl derivative where the formation of the corresponding aziridine was also never observed. ${ }^{12}$ When amine $\mathbf{1 0}$ was further heated in methanol or ethanol for 12 hours under reflux, a mixture of azetidines 11 and 12a,b (as their hydrobromic salt) was obtained. It should be noted that even if the corresponding 2-bromomethyl-2-methylaziridine was formed in this step, it immediately rearranged into azetidines $\mathbf{1 1}$ and $\mathbf{1 2}$ as the thermodynamically preferred products. Heating of amine $\mathbf{1 0}$ in a less nucleophilic solvent such as isopropanol for 16 hours under reflux provided only 3-bromoazetidine hydrobromide 11, which was then isolated as a neutral compound upon treatment with a sodium hydroxide solution in $83 \%$ yield. In addition, treatment of imine $\mathbf{7 b}$ with 1 molar equiv of $\mathrm{LiAlH}_{4}$ in diethyl ether for 18 hours under reflux gave 3-bromoazetidine $\mathbf{1 1}$ as the major product (75\%), together with some non-identified side products (Scheme 2). Again, no traces of 2-bromomethyl-1-t-butyl-2methylaziridine were observed. 


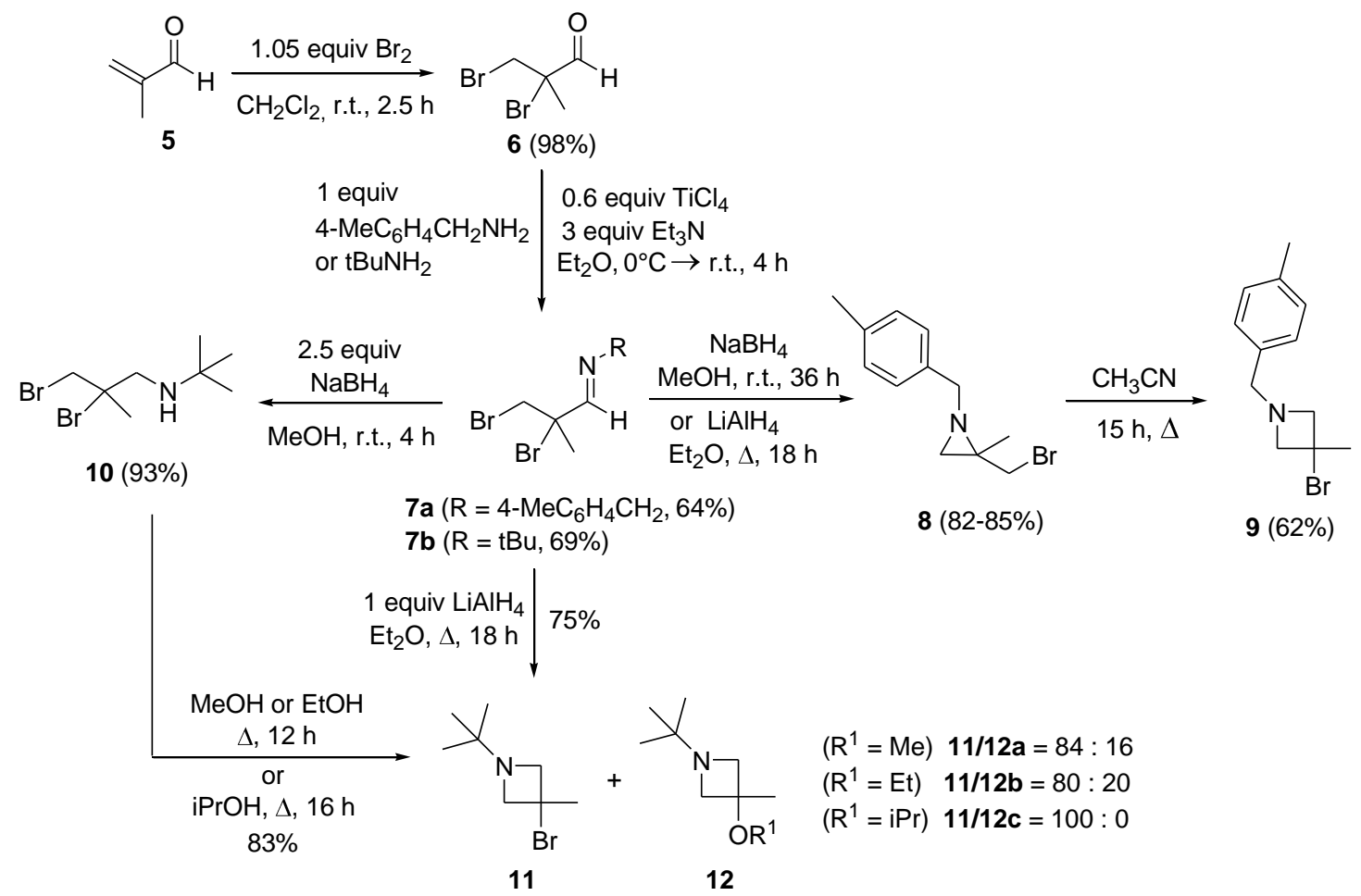

Scheme 2. Synthesis of 3-bromo-3-methylazetidines $\mathbf{9}$ and $\mathbf{1 1 .}$

The formation of 3-alkoxyazetidines 12a,b from amine $\mathbf{1 0}$ is proposed to occur via nucleophilic attack of the solvent molecule (methanol or ethanol) at the more-substituted carbon atom of the intermediate bicyclic aziridinium ion 13 (Scheme 3). This strained intermediate $\mathbf{1 3}$ is most probably formed via intramolecular nucleophilic displacement of bromide in the initially formed 3-bromoazetidine 11. The proposed pathway concurs with the previously reported synthesis of 3-methoxy-3-methylazetidines $3\left(\mathrm{R}^{1}=\mathrm{CH}_{2} \mathrm{Ar}, \mathrm{R}^{2}=\mathrm{Me}\right.$, Scheme 3) comprising the smooth ring expansion of 2-bromomethyl-2-methylaziridines 2 via bicyclic aziridinium intermediates $\mathbf{1 4}$ upon heating in methanol in the presence of $\mathrm{NaBH}_{4}{ }^{7}$ In the same study, it has been shown that 3-methoxy-3-methylazetidines $\mathbf{3}$ can also be obtained starting from 3-bromoazetidines 4 applying the same reaction conditions $\left(\mathrm{NaBH}_{4}, \mathrm{MeOH}, \Delta\right)$. 


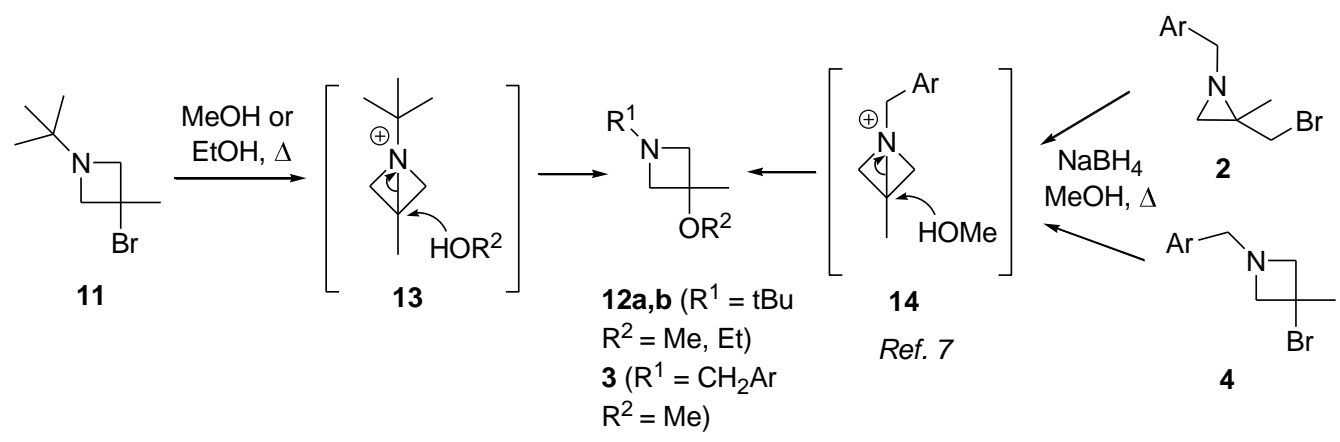

Scheme 3. Synthesis of 3-alkoxy-3-methylazetidines 12.

The latter transformation served as a starting point to thoroughly investigate the synthetic potential of 3-bromo-3-methylazetidines for the preparation of novel 3-substituted azetidines. For this purpose, 3-bromo-3-methyl-1-(4-methylbenzyl)azetidine 9 and 3-bromo-1-t-butyl-3methylazetidine $\mathbf{1 1}$ were selected as eligible substrates for reactions with different nucleophiles.

Upon heating of 3-bromo-1-t-butylazetidine $11(\mathrm{R}=\mathrm{tBu})$ in different alcohols $(\mathrm{MeOH}$, $\mathrm{EtOH}, \mathrm{PrOH}$ ) for 24-72 hours under reflux, the corresponding 3-alkoxyazetidines 12a-c were formed in pure form after basic work-up (Scheme 4). Furthermore, the reactions of azetidines 9 and 11 with 1-2.2 equiv of different phenols and 2-5 equiv of $\mathrm{K}_{2} \mathrm{CO}_{3}$ in tetrahydrofuran or acetonitrile for 4-48 hours under reflux provided the corresponding 3aryloxyazetidines 15a-d in good yields, which were purified by means of column chromatography on silica gel in order to obtain analytically pure samples. ${ }^{13}$ When substrates 9 and 11 were heated in water or water/ $\mathrm{CH}_{2} \mathrm{Cl}_{2}$ (9/1) for 10-24 hours under reflux in the presence of 5 equiv of $\mathrm{KOH}$ or 2 equiv of $\mathrm{K}_{2} \mathrm{CO}_{3}, 1$-t-butyl-3-methyl-3-azetidinol 16a and 3methyl-1-(4-methylbenzyl)-3-azetidinol 16b were obtained in high yields (Scheme 4). ${ }^{14}$ The above-described findings support the suitability of 3-bromo-3-methylazetidines as substrates for nucleophilic substitutions by different oxygen-centered nucleophiles. 


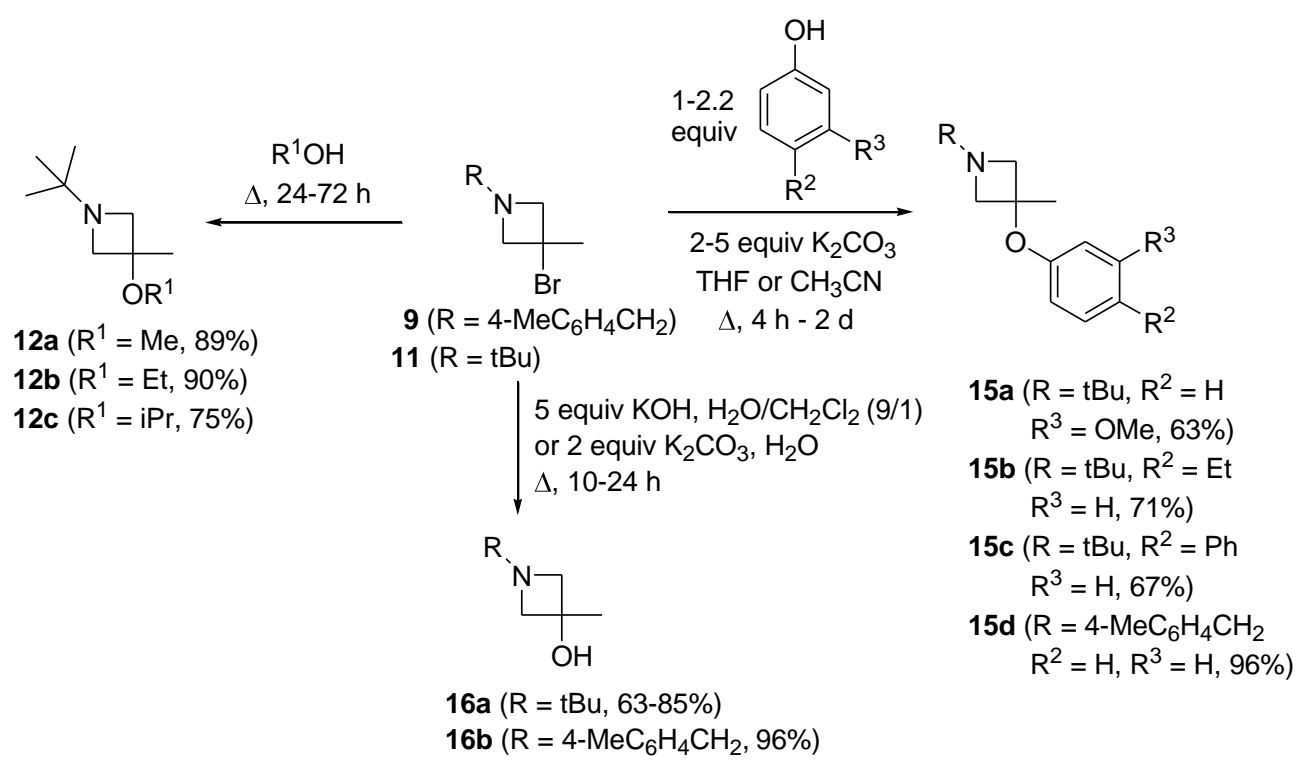

Scheme 4. Reactivity of 3-bromo-3-methylazetidines $\mathbf{9}$ and $\mathbf{1 1}$ towards oxygen nucleophiles.

In the literature, it is known that azetidine-3-carbonitriles can be prepared via nucleophilic substitution of 3-mesyloxy- and 3-tosyloxyazetidines. ${ }^{15}$ In that respect, 3-bromo-3methylazetidines $\mathbf{9}$ and $\mathbf{1 1}$ were also shown to be good substrates for the synthesis of azetidine-3-carbonitriles $\mathbf{1 7 a}, \mathbf{b}$ upon treatment with 1.5 equiv of $\mathrm{KCN}$ in dimethylsulfoxide or acetonitrile for 13-22 hours under reflux (Scheme 5). Azetidine 17a was purified via distillation and azetidine $\mathbf{1 7} \mathbf{b}$ by means of column chromatography on silica gel, which were then used for further derivatization.

The hydrolysis of the cyano group in azetidines $\mathbf{1 7}$ can provide an access towards cyclic amino acids which can be considered as analogues of azetidine-2-carboxylic acid, a natural molecule isolated from Convallaria majalis (lily-of-the-valley) and endowed with impressive biological activities such as the inhibition of the proliferation of Escherichia coli, alteration of the structure of collagen, keratin and haemoglobin in human proteins, and teratogenic effects and various malformations in animals. ${ }^{1 \mathrm{e}}$ Thus, the reaction of azetidine 17a with 5 equiv of $\mathrm{KOH}$ in ethanol under reflux resulted in the corresponding new amino acid 1-tbutyl-3-methylazetidine-3-carboxylic acid 18 (23\% after purification on a Dowex column) after a prolonged reaction time (120 hours) and without traces of the corresponding amide. The carboxy group in azetidine $\mathbf{1 8}$ was then successfully reduced using 2 molar equiv of $\mathrm{LiAlH}_{4}$ in diethyl ether for 3 hours at room temperature to form 3-(hydroxymethyl)azetidine $\mathbf{1 9}$ in $90 \%$ yield. Furthermore, 3-(aminomethyl)azetidine $\mathbf{2 0}$ was obtained after reduction of 
the cyano group with 2 molar equiv of $\mathrm{LiAlH}_{4}$ in diethyl ether for 14 hours at room temperature. ${ }^{16}$

A number of experiments were also performed concerning the hydrolysis of the cyano group in 1-(4-methylbenzyl)azetidine-3-carbonitrile $\mathbf{1 7 b}$. The treatment of azetidine $\mathbf{1 7 b}$ with 5 equiv of $\mathrm{KOH}$ in $\mathrm{EtOH} / \mathrm{H}_{2} \mathrm{O}(5 / 1)$ under microwave irradiation $\left(150{ }^{\circ} \mathrm{C}, 15 \mathrm{~min}, 150 \mathrm{~W}\right)$ and subsequent neutralization with a solution of hydrochloric acid (1M) gave the corresponding new amino acid 21. Interestingly, two isomeric structures (ratio 3/2) of azetidine 21 were observed upon NMR analysis $\left(\mathrm{CD}_{3} \mathrm{OD}\right)$, which can be attributed to the zwitterionic nature of this compound providing two diastereomeric counterparts. The purification of amino acid $\mathbf{2 1}$ on Dowex $\mathrm{H}^{+}\left(\mathrm{NH}_{4} \mathrm{OH}\right)$ afforded ammonium 3-methyl-1-(4-methylbenzyl)azetidine-3carboxylate 22 as a single isomer in pure form. ${ }^{17}$ These observations further support the synthetic utility of 3-bromo-3-methylazetidines as substrates for nucleophilic displacements, e.g. towards the synthesis of versatile 3-methylazetidine-3-carbonitriles.

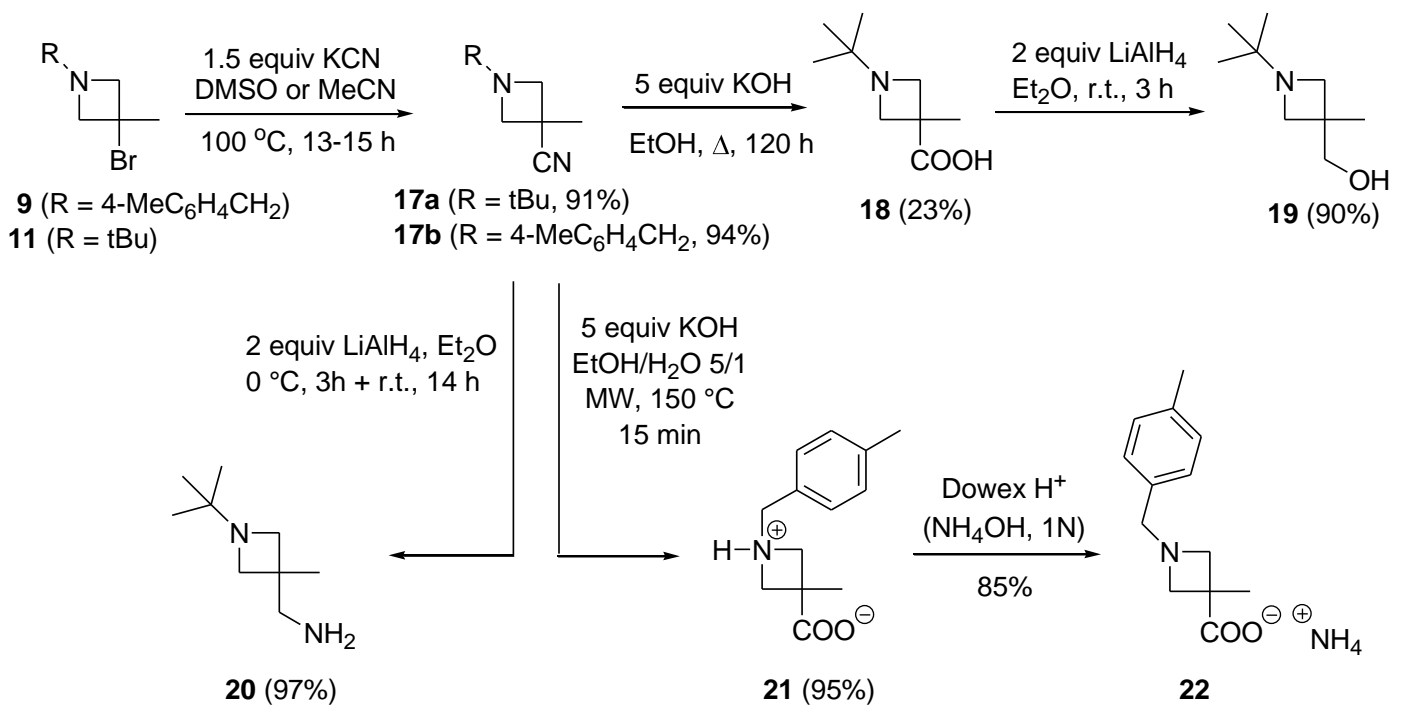

Scheme 5. Synthesis and reactivity of 3-methylazetidine-3-carbonitriles $\mathbf{1 7 a}, \mathbf{b}$.

In conclusion, efficient syntheses of 3-bromo-3-methylazetidines 9 and $\mathbf{1 1}$ were disclosed starting from 2-bromomethyl-2-methylaziridine $\mathbf{8}$ and $\beta, \gamma$-dibrominated amine $\mathbf{1 0}$, respectively. Through a number of examples, the azetidines $\mathbf{9}$ and $\mathbf{1 1}$ were shown to easily undergo nucleophilic substitution with different nucleophiles, providing a convenient method for the preparation of new synthetically and biologically attractive 3-substituted azetidines $\mathbf{2 3}$ 
such as 3-alkoxy-, 3-aryloxy-, 3-hydroxy-, 3-cyano-, 3-carboxy-, 3-(aminomethyl)- and 3(hydroxymethyl)azetidines (Scheme 6).

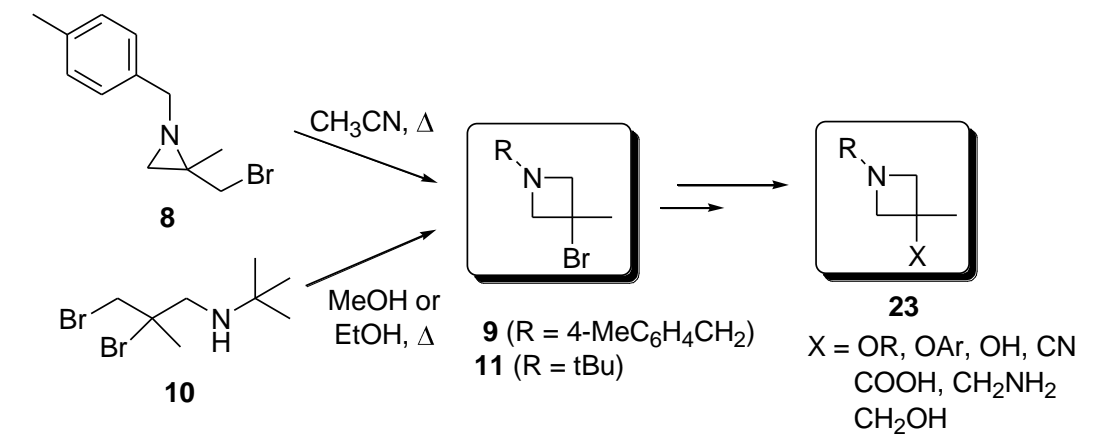

Scheme 6. 3-Bromo-3-methylazetidines 9 and $\mathbf{1 1}$ as building blocks for the preparation of 3substituted 3-methylazetidines 23.

\section{Acknowledgments}

This work was supported by the Research Foundation-Flanders (FWO-Vlaanderen) and the Research Board of Ghent University (BOF-GOA).

\section{References and notes}

\# Present address: Department of Chemistry, Faculty of Science, University of Antwerp, Middelheimcampus, G.V.211, Groenenborgerlaan 171, 2020 Antwerpen, Belgium.

${ }^{1}$ (a) Cromwell, N. H.; Phillips, B. Chem. Rev. 1979, 79, 331-358. (b) Moore, J. A.; Ayers, R. S. Chemistry of Heterocyclic Compounds-Small Ring Heterocycles; Hassner, A., Ed.; Wiley: New York, NY, 1983; Part 2, pp 1-217. (c) Davies, D. E.; Storr, R. C. Comprehensive Heterocyclic Chemistry; Lwowski, W., Ed.; Pergamon: Oxford, 1984; Vol. 7, Part 5, pp $237-$ 284. (d) Singh, G. S.; D'hooghe, M.; De Kimpe N. "Azetidines, Azetines, and Azetes: Monocyclic" in Comprehensive Heterocyclic Chemistry III, a review of the literature 19952007, Katritzky, A.; Ramsden, C.; Scriven, E.; Taylor, R. (Eds.), Elsevier, Oxford, 2008, Vol. 2, p 1-110. (e) Couty, F.; Evano, G. Org. Prep. Proced. Int., 2006, 38, 427-465. (f) Ferraris, D.; Belyakov, S.; Li, W. X.; Oliver, E.; Ko, Y. S.; Calvin, D.; Lautar, S.; Thomas, B.; Rojas, C. Curr. Top. Med. Chem., 2007, 7, 597-608.

2 (a) Bagal, S. K.; Davies, S. G.; Lee, J. A.; Roberts, P. M.; Russell A. J.; Scott, P. M.; Thomson, J. E. Org. Lett. 2010, 12, 136-139. (b) Feula, A.; Male, L.; Fossey, J. S. Org. Lett. 
2010, 12, 5044-5047. (c) Brown, M. J.; Clarkson, G. J.; Inglis, G. G., Shipman, M. Org. Lett. 2011, 13, 1686-1689. (d) Couty, F.; Durrat, F.; Prim, D. Tetrahedron Lett. 2003, 44, 52095212. (e) Couty, F.; Evano, G. Synlett 2009, 3053-3064. (f) Couty, F. Science of Synthesis 2009, 773-817. (g) Couty, F.; Durrat, F.; Evano, G. Targets Heterocycl. Syst. 2005, 9, 186210. (h) Brandi, A.; Cicchi, S.; Cordero, F. M. Chem. Rev. 2008, 108, 3988-4035. (i) Couty, F.; Evano, G.; Prim, D. Minirev. Org. Chem. 2004, 1, 133-148. (j) Couty, F.; David, O.; Durrat, F.; Evano, G.; Lakhdar, S. Marrot, J.; Vargas-Sanchez, M. Eur. J. Org. Chem. 2006, 3479-3490.

3 Fyfe, M. C. T.; Gattrell, W.; Rasamison, C. M. PCT Int. Appl. 2007, WO 2007116230 Al; Chem. Abstr. 2007, 147, 469218.

${ }^{4}$ Isabel, E.; Oballa, R.; Powell, D.; Robichaud, J. PCT Int. Appl. 2007, WO 2007143823 Al; Chem. Abstr. 2007, 148, 78872.

5 Josyula, V. P. V. N.; Renslo, A. R. PCT Int. Appl. 2007, WO 2007004049 Al; Chem. Abstr. 2007, 146, 142631.

${ }^{6}$ Van Brabandt, W.; Mangelinckx, S.; D’hooghe, M.; Van Driessche, B.; De Kimpe, N. Curr. Org. Chem. 2009, 13, 829-853.

${ }^{7}$ Stanković, S.; Catak, S.; D’hooghe, M.; Goossens, H.; Abbaspour Tehrani, K.; Bogaert, P.; Waroquier, M.; Van Speybroeck, V.; De Kimpe, N. J. Org. Chem. 2011, 76, 2157-2167.

${ }^{8}$ De Kimpe, N.; De Smaele, D. Tetrahedron 1995, 51, 5465-5478.

9 (a) De Kimpe, N.; Jolie, R.; De Smaele, D. J. Chem. Soc. Chem. Commun. 1994, 12211222. (b) D'hooghe, M.; Waterinckx, A.; De Kimpe, N. J. Org. Chem. 2005, 70, 227-232. (c) Sulmon, P.; De Kimpe, N.; Schamp, N.; Tinant, B.; Declercq, J.-P. Tetrahedron 1988, 44, 3653-3670.

10 (a) Mangelinckx, S.; Žukauskaitè, A.; Buinauskaitè, V.; Šačkus, A.; De Kimpe, N. Tetrahedron Lett. 2008, 49, 6896. (b) Gaertner, V. R. J. Org. Chem. 1970, 35, 3952-3959. (c) Žukauskaitè, A.; Mangelinckx, S.; Buinauskaitè, V.; Šačkus, A.; De Kimpe, N. Amino Acids 2011, 41, 541-558.

${ }^{11}$ (a) Stanković, S.; D’hooghe, M.; De Kimpe, N. Org. Biomol. Chem., 2010, 8, 4266-4273. (b) De Kimpe, N.; Verhé, R.; De Buyck, L.; Schamp, N. J. Org. Chem. 1981, 46, 2079-2081. (c) De Kimpe, N.; Verhé, R.; De Buyck, L.; Schamp, N. Bull. Soc. Chim. Belg. 1983, 92, 233-239. (d) Vilhelmsen, M. H.; Ostergaard, L. F.; Nielsen, M. B., Hammerum, S. Org. Biomol. Chem. 2008, 6, 1773-1778. 
${ }^{12}$ Stanković, S.; D’hooghe, M.; Dewulf, J.; Bogaert, P.; Jolie, R.; De Kimpe, N. Tetrahedron Lett. 2011, 52, 4529-4532.

13 As a representative example, the synthesis of 1-t-butyl-3-(4-ethylphenoxy)-3methylazetidine 15b is described here. 3-Bromo-1-t-butyl-3-methylazetidine 11 (1.03 g, 5 mmol) was dissolved in THF (10 mL), after which 4-ethylphenol (0.61 g, 1 equiv) and $\mathrm{K}_{2} \mathrm{CO}_{3}(1.38 \mathrm{~g}, 2$ equiv) were added, and the mixture was stirred for 48 hours under reflux. The reaction mixture was poured into an aqueous sodium hydroxide solution $(1 \mathrm{M}, 15 \mathrm{~mL})$ and extracted with $\mathrm{CH}_{2} \mathrm{Cl}_{2}(3 \times 15 \mathrm{~mL})$. The combined organic extracts were washed with $\mathrm{H}_{2} \mathrm{O}(2 \times 15 \mathrm{~mL})$ and brine $(15 \mathrm{~mL})$. Drying $\left(\mathrm{MgSO}_{4}\right)$, filtration of the drying agent and evaporation of the solvent afforded 1-t-butyl-3-(4-ethylphenoxy)-3-methylazetidine $\mathbf{1 5 b}(0.88$ g, 71\%), which was purified by column chromatography $\left(\mathrm{CH}_{2} \mathrm{Cl}_{2} / \mathrm{MeOH} 96 / 4, \mathrm{R}_{\mathrm{f}}=0.15\right)$ in order to obtain an analytically pure sample. 1-t-Butyl-3-(4-ethylphenoxy)-3-methylazetidine 15b: Yield 71\%; ${ }^{1} \mathrm{H}$ NMR (270 MHz, $\left.\mathrm{CDCl}_{3}\right) \delta 0.97(9 \mathrm{H}, \mathrm{s}), 1.21(3 \mathrm{H}, \mathrm{t}, J=7.6 \mathrm{~Hz}), 1.68$ $(3 \mathrm{H}, \mathrm{s}), 2.58(2 \mathrm{H}, \mathrm{q}, J=7.6 \mathrm{~Hz}), 3.32(2 \mathrm{H}, \mathrm{d} x \mathrm{~d}, J=6.9,1.6 \mathrm{~Hz}), 3.45(2 \mathrm{H}, \mathrm{d}, J=6.9), 6.64-$ 7.07 (4H, m). ${ }^{13} \mathrm{C}$ NMR (67.8 MHz, $\left.\mathrm{CDCl}_{3}\right) \delta 15.8,22.0,24.2,27.9$, 52.0, 58.8, 72.1, 116.7, 128.6, 136.5, 153.2. IR $\left(\mathrm{NaCl}, \mathrm{cm}^{-1}\right) v_{\max }=2958,1602,1503,1356,1310,1228,828$. MS (70 eV) m/z (\%) 247 (M+ 5), 232 (16), 163 (15), 162 (100), 147 (12), 133 (36), 122 (21), 120 (14), 119 (57), 107 (44), 86 (28), 70 (30), 57 (18), 55 (14).

14 As a representative example, the synthesis of 3-methyl-1-(4-methylbenzyl)-3-azetidinol 16b is described here. 3-Bromo-3-methyl-1-(4-methylbenzyl)azetidine 9 (1.27 g, 5 mmol) was added to a two-phase solvent system $\left(\mathrm{H}_{2} \mathrm{O} / \mathrm{CH}_{2} \mathrm{Cl}_{2}\right.$ 9/1, $\left.15 \mathrm{~mL}\right)$, after which $\mathrm{KOH}(1.40 \mathrm{~g}$, 5 equiv) was added, and the mixture was stirred for 10 hours under reflux. The reaction mixture was poured into water $(15 \mathrm{~mL})$ and extracted with $\mathrm{CH}_{2} \mathrm{Cl}_{2}(3 \times 15 \mathrm{~mL})$. The combined organic extracts were washed with $\mathrm{H}_{2} \mathrm{O}(2 \times 15 \mathrm{~mL})$ and brine $(15 \mathrm{~mL})$. Drying $\left(\mathrm{MgSO}_{4}\right)$, filtration of the drying agent and evaporation of the solvent afforded 3-methyl-1(4-methylbenzyl)-3-azetidinol $\mathbf{1 6 b}$ as white crystals (0.92 g, purity > 95\% based on NMR analysis). 3-Methyl-1-(4-methylbenzyl)-3-azetidinol 16b: White crystals; $\mathrm{Mp}=85.3{ }^{\circ} \mathrm{C}$. Yield 96\%; ${ }^{1} \mathrm{H}$ NMR (300 MHz, $\left.\mathrm{CDCl}_{3}\right) \delta 1.40(3 \mathrm{H}, \mathrm{s}), 2.25(3 \mathrm{H}, \mathrm{s}), 2.99$ and $3.20(4 \mathrm{H}, 2 \mathrm{x}$ d, $J=6.9 \mathrm{~Hz}), 3.53(3 \mathrm{H}, \mathrm{s}), 7.02-7.10(4 \mathrm{H}, \mathrm{m}) .{ }^{13} \mathrm{C} \mathrm{NMR}\left(75 \mathrm{MHz}\right.$, ref $\left.=\mathrm{CDCl}_{3}\right) \delta 21.2$, 26.1, 63.2, 68.0, 68.9, 128.6, 128.8, 134.9, 136.8. IR (neat, $\left.\mathrm{cm}^{-1}\right) v_{\mathrm{OH}}=3359$. MS $(70 \mathrm{eV}) \mathrm{m} / \mathrm{z}$ (\%) $192\left(\mathrm{M}^{+}+1,100\right)$.

15 (a) Okutani, T.; Kaneko, K.; Masuda, K. Chem. Pharm. Bull. 1974, 22, 1490-1497. (b) Okutani, T.; Masuda, K. Chem. Pharm. Bull. 1974, 22, 1498-1505. (c) Gaertner, V. R. J. Org. 
Chem. 1970, 35, 3952-3959. (d) Higgins, R. H.; Doomes, N. H.; Cromwell, N. H. J. Heterocycl. Chem. 1971, 8, 1063-1067.

${ }^{16}$ Synthesis of 3-aminomethyl-1-t-butyl-3-methylazetidine 20. To an ice-cooled solution of 1-t-butyl-3-methylazetidine-3-carbonitrile 17a $(0.76 \mathrm{~g}, 5 \mathrm{mmol})$ in dry diethyl ether $(10 \mathrm{~mL})$, $\mathrm{LiAlH}_{4}$ (0.38 g, 2 equiv) was slowly added, and the reaction mixture was stirred first for 3 hours at $0{ }^{\circ} \mathrm{C}$, and then for 14 hours at room temperature. The resulting mixture was poured cautiously into water $(15 \mathrm{~mL})$ and extracted with $\mathrm{Et}_{2} \mathrm{O}(3 \times 15 \mathrm{~mL})$. The combined organic extracts were washed with $\mathrm{H}_{2} \mathrm{O}(2 \times 15 \mathrm{~mL})$ and brine $(15 \mathrm{~mL})$. Drying $\left(\mathrm{MgSO}_{4}\right)$, filtration of the drying agent and evaporation of the solvent afforded 3-aminomethyl-1-t-butyl-3methylazetidine $20(0.76 \mathrm{~g}, 97 \%)$ in high purity (purity > 95\% based on NMR analysis). 3Aminomethyl-1- $t$-butyl-3-methylazetidine 20: Yield 97\%; ${ }^{1} \mathrm{H}$ NMR $\left(270 \mathrm{MHz}, \mathrm{CDCl}_{3}\right) \delta$ $0.94(9 \mathrm{H}, \mathrm{s}), 1.18(3 \mathrm{H}, \mathrm{s}), 1.63(2 \mathrm{H}$, broad s), $2.78(2 \mathrm{H}, \mathrm{s}), 2.91$ and $3.03(4 \mathrm{H}, 2 \mathrm{x} \mathrm{d}, J=7.3$ $\mathrm{Hz}) .{ }^{13} \mathrm{C} \mathrm{NMR}\left(67.8 \mathrm{MHz}, \mathrm{CDCl}_{3}\right) \delta 22.7,24.1,33.4,50.9,51.6,55.2 . \mathrm{IR}\left(\mathrm{NaCl}, \mathrm{cm}^{-1}\right) v_{\mathrm{NH} 2}$ = 3680-3000. MS (70eV) m/z (\%) no $\mathrm{M}^{+}, 141\left(\mathrm{M}^{+}-\mathrm{Me}, 58\right), 84$ (36), 72 (72), 70 (100), 57 (69), 55 (47), 49 (35).

17 Synthesis of ammonium 3-methyl-1-(4-methylbenzyl)azetidine-3-carboxylate 22. 1-(4Methylbenzyl)azetidine-3-carbonitrile $\mathbf{1 7 b}(0.20 \mathrm{~g}, 1 \mathrm{mmol})$ was dissolved in $\mathrm{EtOH} / \mathrm{H}_{2} \mathrm{O}$ (5/1, $5 \mathrm{~mL})$, after which $\mathrm{KOH}(0.28 \mathrm{~g}, 5$ equiv) was added. The mixture was placed in an 6$\mathrm{mL}$ sealed glass vessel, provided with an appropriate stirring bar and subjected to microwave conditions $\left(150{ }^{\circ} \mathrm{C}, 15 \mathrm{~min}, 150 \mathrm{~W}\right)$. The reaction mixture was neutralized with a solution of hydrochloric acid $(1 \mathrm{M})$ to $\mathrm{pH}=7$ and water was evaporated under high vacuum. Purification of amino acid 21 (two isomeric forms confirmed by NMR analysis) by means of ionexchange chromatography on Dowex $\mathrm{H}^{+}(50$ x 8-100) afforded ammonium 3-methyl-1-(4methylbenzyl)azetidine-3-carboxylate $22(0.20 \mathrm{~g}, 85 \%)$. White crystals; Mp > $350{ }^{\circ} \mathrm{C}$. Yield 85\%; ${ }^{1} \mathrm{H}$ NMR (300 MHz, CD $\left.3 \mathrm{OD}\right) \delta 1.41(3 \mathrm{H}, \mathrm{s}), 2.24(3 \mathrm{H}, \mathrm{s}), 3.73$ and $4.20(4 \mathrm{H}, 2 \mathrm{x} \mathrm{d}, J=$ $10.7 \mathrm{~Hz}), 4.20(2 \mathrm{H}, \mathrm{s}), 7.16-7.27(4 \mathrm{H}, \mathrm{m}) .{ }^{13} \mathrm{C}$ NMR (75 MHz, $\left.\mathrm{CD}_{3} \mathrm{OD}\right) \delta 21.3,23.3,42.3$, 59.4, 63.7, 128.6, 131.0, 131.1, 141.2, 180.5. IR (neat, $\left.\mathrm{cm}^{-1}\right) v_{\mathrm{CO}}=1603 . \mathrm{MS}(70 \mathrm{eV}) \mathrm{m} / \mathrm{z}(\%)$ $218\left(\mathrm{M}^{+}+1,100\right)$. 